strange monument in the history of science find also somewhere speedy reissue?

\section{Austrin, Texas.}

\section{George Bruce Halsted.}

The Psychology of Suggestion. By BorIs Srdis, M.A., Ph.D., Associate in Psychology at the Pathological Institute of the New York State Hospitals. With an Introduction by ProFESSOR WILLIAM JAMEs, of Harvard University. New York, D. Appleton \& Co. 1898. Dr. Sidis divides his book into three parts, entitled, respectively, 'Suggestibility,' 'The Self,' and 'Society.' The interest of the first centers in two series of laboratory experiments and is intended to establish the "Laws of Normal and Abnormal Suggestibility.' The second aims at establishing in every human being the existence of a 'Subwaking Self,' determining its intrinsic character, its relation to the primary self, its physiological conditions, and its relation to the phenomena of amnesia and insanity. The third ascribes to the activity of the subwaking self, stampedes, social epidemics, and in general the peculiar traits of crowd and mob psychology.

Suggestion is defined as 'the intrusion into the mind of an idea; met with more or less opposition by the person; accepted uncritically at last; and realized unreflectively, almost automatically.'

This definition has obviously been framed with the thought of normal suggestibility in mind, for in states of heightened, or, as Dr. Sidis would term it, abnormal suggestibility, the idea frequently meets with no opposition whatever. Nothing is more common than to see such patients anxiously consider and deliberately realize the suggestions given them. To make it apply throughout, the suggestion should be described as an idea which would be met with more or less opposition in the normal state, but which in the normal state is accepted, usually uncritically, and realized, often unreflectively, while in the abnormal state it meets with little or no opposition.

Yet even as thus amended, the definition would require us to show, before any intruded and realized idea can be termed a suggestion, that it would have met with opposition, of which we have usually no better criterion than such as our knowledge of the tastes and habits of the individual in question can supply.

In Dr. Sidis' series of experiments he endeavored, by very ingenious means, to determine the subject's flow of ideas or to affect his choice of a limited number of alternatives without attracting his attention to the method by which he was influenced. The results are interesting, although one would like to have more precise information as to the conditions under which they were obtained. The main conclusion which Dr. Sidis deduces from these experiments he generalizes into the ' Law of Normal Suggestibility'-'Normal Suggestibility varies as indirect suggestion and inversely as direct suggestion.' Then after a review of the phenomena of hypnosis, he sets over against this 'The Law of Abnormal Suggestibility,' which 'varies as direct. suggestion and inversely as indirect suggestion.'

Unfortunately, the distinction between direct and indirect suggestion has nowhere been defined. From the illustrations given, however, we may infer that a suggestion is indirect when it is so administered that it never passes beyond: the marginal region. It then remains a mere seed upon the surface of consciousness, never strikes its roots down into the depths below, is merely apprehended and not comprehended. A normally repugnant intruded idea will then be less likely to arouse opposition and more likely to gain its ends if indirect than if direct, and the first law may be accepted as so far true even without experimental verification. But it should be noted that the numerous cases in which the opposition of the self-consciousness to a direct. suggestion is overborne by sheer superior strength of will must be relegated to the class. of abnormal suggestions - a more than questionable proceeding.

The second law, however, is by no means: true. Increased susceptibility to direct suggestion does not carry with it diminished susceptibility to indirect suggestion. In states of heightened suggestibility, susceptibility to suggestion has no significant relation to the mode in which the suggestion is administered, but rather to the source whence it comes. A subject who is acutely sensitive to every suggestion, direct or indirect, that emanates from the person. 
who has hypnotized him, will be, as a rule, absolutely obtuse to the most direct of suggestions given by any other person. Rapport, although not an inevitable, is perhaps one of the most constant traits of heightened suggestibility, and this Dr. Sidis' second law ignores. Furthermore, it puts in an inverse relation traits that usually vary directly.

In his theory of the 'subwaking self,' Dr. Sidis takes ground between Myers and Pierre Janet. With Myers he holds that the subwaking self is a normal constituent of every human being and is not merely a 'disaggregation phenomenon.' With Pierre Janet he denies to it personality and self-consciousness, save in rare cases, and describes it as a congeries of ill coordinated, extremely suggestible, dreamlike states. He further concludes that it is possessed of acute senses, but lacks sense and all power of criticism, is servile, cowardly, devoid of morality and of the power of willing. The relation between the primary and secondary selves is not clearly defined. Intercommunication exists, however, to some extent, and the phenomena of hypnosis, suggestibility, automatism, amnesia, insanity and of crowd and mob psychology are ascribed to a dissociation between the two selves whereby the inhibition of the primary is removed and the peculiar traits of the secondary are allowed to come to light.

To frame his physiological theory, Dr. Sidis simply substitutes for his 'moments content,' or psychic element, the nerve-cell, for association, contact of terminal filaments, for dissociation retraction of the terminal filaments and consequent loss of contact. Quite apart from the doubt cast upon 'no-anastomosis-but-approximation-only' theory by the recent publication of Apáthy's work, there never has been any physiological evidence for the theory which Dr. Sidis adopts. It rests solely upon anatomical observations and should not be put forward without due recognition of its speculative character.

But if Dr. Sidis' passion for logical clearness and exact formulation has betrayed him into making generalizations upon insufficient data, it has none the less made his book the more interesting. Even where the daring of his state- ments challenges dissent, one cannot but feel sympathy for these bold attempts to introduce order into chaos, and for the scientific enthusiasm which inspired them. Attention should also be called to the interesting case of amnesia of which a brief account is given in Chapter XXII. and to the even more interesting series of experiments upon subconscious perception.

Wm. Romaine Newbold.

University of Pennsyluania.

Erkenntnistheoretische Grundzüge der Naturwissenschaften und ihre Beziehungen zum Geistesleben der Gegenwart. P. VoLKMANN. Leipzig, Teubner. Pp. xii +181 .

Étude critique du matérialisme et du spirituaiisme par la physique expérimèntale. RAOUL Pictet. Geneva, Georg \& Co. Pp. xix +596 . Readers of SCIENCE who see also the columns of Nature may remember that the former of the above-named books was made not long ago the occasion of a rather sharp polemic by Dr. Karl Pearson on 'the departing glory of German science.' Now it may well be that Dr. Pearson's extended reading justifies his contention of the decadence of science in Germany, but certainly his illustrative examples were hardly well chosen. The Grundzüge is not a great book. It may even be one of a class of books not worth writing-an attempt to explain and to justify to a popular audience the scientific movement of the time. The critic justly charges the book with vagueness; with incompleteness; with failure in a labored effort to distinguish between certain scientific terms, as law, rule, principle, hypothesis ; and especially with pushing too far loose analogies drawn from natural science and applied to other fields of thought.

But he is particularly severe upon Professor Volkmann for not seeming to have clear vision of the truth that all so-called natural laws are simply laws of the mind. Now the fact is that the book before us is as emphatic as Dr. Pearson himself could be in declaring that scientific laws are always and everywhere, like those of mathematics, constructions of the mind ; only the author adds, these constructions must conform to experience. See p. 57, etc.

But the criticism is mainly unsatisfactory in 